\title{
A STUDY OF SHORT TERM CHRONIC PULMONARY TOXICITY, NEUROTOXICITY AND GENOTOXICITY OF COPPER OXIDE NANOPARTICLES AND THE POTENTIAL PROTECTIVE ROLE OF VITAMIN E ON ADULT MALE ALBINO RATS
}

\author{
Barakat $W^{1}$, Wasef $M^{1}$, Abass $M^{1}$ and Elnegris $\mathbf{H}^{2}$ \\ ${ }^{1}$ Department of Forensic Medicine \& Clinical Toxicology, Faculty of Medicine, \\ Zagazig University, Egypt. \\ ${ }^{2}$ Department of Histology and Cell biology, Faculty of Medicine, Zagazig \\ University, Egypt
}

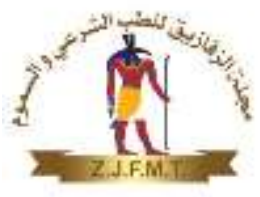

\begin{abstract}
Copper oxide nanoparticles ( $\mathrm{CuO}$ NPs) are widely used as semiconductors and in antibacterial medications. They have been reported to elicit various adverse effects including oxidative stress and DNA damage. Vitamin $E$ has been reported to protect against lipid peroxidation induced tissue damage. The aim of this work was to investigate the short term chronic pulmonary toxicity, neurotoxicity and genotoxicity of $\mathrm{CuO}$ NPs and evaluate the protective role of vitamin $\mathrm{E}$ against $\mathrm{CuO}$ NPs toxicity in adult male albino rats. Seventy two adult male albino rats were used in this study. They were divided into 5 groups: Negative control group (I), Positive control group (II) subdivided into 2 groups: (IIA) and (IIB), Vitamin E treated group (III), CuO NPs treated group (IV) and CuO NPs + vitamin E treated group (V). After 4 and 8 weeks, 6 rats from each group subjected to blood sample collection for estimating MDA. The rats were sacrificed and the brain and lungs were dissected and divided into three parts. The first part was used for estimating copper content in the brain and lungs. The second part was used to determine the extent of DNA damage. The third part was subjected to microscopic histopathological, and immunohistochemical examination. The results revealed that $\mathrm{CuO}$ NPs administration induced a significant increase in serum MDA and in copper content in the brain and the lungs. CuO NPs produced DNA damage and histopathological alteration in the brain and the lungs with increased caspase 3 immunoreactivity. Vitamin E produced improvement in serum MDA, histopathological changes and caspase 3 immunoreactivity with protective effect against DNA damage. Conclusion: $\mathrm{CuO}$ NPs induced toxic effects and DNA damage in the brain and the lungs and administration of vitamin $\mathrm{E}$ with $\mathrm{CuO}$ NPs offers protection against their damaging effect.
\end{abstract}

Key words: Copper oxide nanoparticles, Genotoxicity, Neurotoxicity, Oxidative stress, Pulmonary Toxicity, Vitamin E.

\section{1-INTRODUCTION}

$\mathbf{N}$ anotechnology is a new branch of science, which has the potential to solve many problems in different fields (Ingle et al., 2014). The production of nanoparticles and their use in many fields has increased remarkably in the last decade. Newly manufactured nanoparticles are being used in a large variety of applications such as computing, electronics, construction, cosmetics, drug delivery, medical imaging, paints, coatings, food, packaging, textiles, clothing and others (Adamcakova-Dodd et al., 2011).

Nanoparticles are particles with lengths that range from 1 to 100 nanometers in two or three dimensions (Lewinski et al., 2008). Previous studies found that materials which were considered inert were causing enhanced toxic responses if used at nanosize (Kaewamatawong et al., 2005).
Metal oxide nanoparticles have been receiving considerable attention for their potential applications in optoelectronics, nanodevices, nanoelectronics, nanosensors, information storage and catalysis. Among various metal oxide nanoparticles, $\mathrm{CuO}$ NPs have attracted particular attention because they are the simplest member of the family of copper compounds and show a range of useful physical properties (Ahamed et al., 2014).

Copper oxide $(\mathrm{CuO})$ is a semiconductor metal with unique electrical, optical and magnetic properties. It has been used for many applications such as in magnetic storage media, sensors, catalysis, inks, lubricants, coatings, semiconductors, heat transfer fluids, antimicrobial preparations and intrauterine contraceptive devices (Karmakar et al, 2014 and Grigore et al, 2016).

Even though $\mathrm{CuO}$ NPs have proved their use in biomedical applications, they were 
found to be highly toxic compared to other carbon or metal oxide nanoparticles or copper microparticles. Due to their small size, they may cross biological barriers to reach different organs (Alarifi et al., 2013). They are capable of crossing the blood brain barrier (BBB) and pose a threat to the CNS. Recently, there have been increasing reports showing that inhaled nanoparticles can reach the brain and may be associated with neurodegeneration so it is necessary to evaluate the potential toxic effects of $\mathrm{CuO}$ NPson the brain (Karmakar et al, 2014).

Lung inflammation has been reported in different studies following exposure to $\mathrm{CuO}$ NPs (Cho et al, 2012).

Several in vitro studies have proven that $\mathrm{CuO}$ NPs induced cytotoxic, genotoxic and oxidative stress effects (Lai et al., 2018). The main toxicity process depends on the increased production of reactive oxygen species (Grigore et al, 2016).

Vitamin $\mathrm{E}$ is generally protective against copper induced oxidative damage (Gaetke and Chow, 2003). It is a lipid-soluble vitamin of which $\alpha$-tocopherol is the most active form and it is a powerful biological antioxidant. Vitamin E may effectively minimize oxidative stress, lipid perioxidation and toxic effects of reactive oxygen species in biological systems (Ogutcu et al., 2006). In addition, vitamin $\mathrm{E}$ has been shown to be effective in reducing genotoxic effects of various genotoxic compounds (Singh et al., 2008). The aim of this study was to investigate the short term chronic pulmonary toxicity, neurotoxicity and genotoxicity of copper oxide nanoparticles (CuO NPs) and to evaluate the protective role of vitamin $\mathrm{E}$ against $\mathrm{CuO}$ NPs toxicity in adult male albino rats.

\section{2-MATERIALS AND METHODS}

\subsection{Particle characterization:}

$\mathrm{CuO}$ NPs were in the form of dry black powder (Product No. 544,868, APS: $50 \mathrm{~nm}$ and SSA: 25-40 $\mathrm{m} 2 / \mathrm{g}$ ) manufactured by Sigma-Aldrich chemical company, USA and purchased from Sigma-Egypt (Eltayaran St., Nasr City-Cairo).

The morphology and size of $\mathrm{CuO}$ NPs were determined by transmission electron microscopy (TEM) according to Ahamed et al. (2010). Dry powder of particles was suspended in deionized water at a concentration of $1 \mathrm{mg} / \mathrm{mL}$ and then sonicated at room temperature for $10 \mathrm{~min}$. to form a homogeneous suspension. After sonication and stabilization, the TEM samples were prepared by drop coating of the stock suspension on carbon-coated copper grids. The films on the grids were allowed to dry prior to measurement. TEM measurements were performed at an accelerating voltage of 80 kV (Model JEM-1400, JEOL Ltd., Tokyo, Japan). This characterization was done in Electron Microscopy Unit, Faculty of Agriculture Research Park (FARP), Cairo University, Egypt.

\subsection{Animals and grouping:}

The study was performed in compliance with the relevant laws and guidelines of the Zagazig University of Medicine, Egypt, which are in accordance with the National Institutes of Health Guidelines for Animal Care. A total of 72 male albino rats (weighing 150-200 g) were bred and reared at the animal care center. Animals were acclimated for two weeks under standard laboratory conditions prior to commencement of treatment. Food and water was made available ad libitum. Room temperature was maintained at $23 \pm 2{ }^{\circ} \mathrm{C}, 12 \mathrm{~h}$ light-dark cycles, with a relative humidity of $40-60 \%$. Animals were divided into five groups consisting of 12 animals per group.

- Negative control group (I): rats received only regular diet and water.

- Positive control group (II): subdivided into 2 subgroups: Positive control group (IIA) rats received $1 \mathrm{ml}$ of deionized water and Positive control group (IIB) rats received $1 \mathrm{ml}$ of corn oil.

- Vitamin E treated group (vit. E) (III): rats were gavaged orally with vitamin E (100mg / $\mathrm{kg}$ ) dissolved in corn oil (Yousef et al., 2006).

- CuO NPstreated group (CuO NPs) (IV): rats were gavaged orally with a daily dose of $\mathrm{CuO}$ NPs $(250 \mathrm{mg} / \mathrm{kg})$ which was suspended in deionized water and sonicated with a probe sonicator. (Safety data sheet according to Regulation (EC), SIGMA-ALDRICH, 2014). 
- $\mathrm{CuO}$ NPs + vitamin $\mathrm{E}$ treated group $(\mathrm{CuO}$ NPs + vit.E) (V): rats were gavaged orally with vitamin E (100mg / kg) dissolved in corn oil then after one hour the rats were gavaged orally with a daily dose of $\mathrm{CuO}$ NPs $(250 \mathrm{mg} / \mathrm{kg})$ which was suspended in deionized water and sonicated with a probe sonicator.

All treatments were given once daily for 8 weeks. After the end of 4 weeks and 8 weeks, 6 rats from each group were sacrificed.

\subsection{Specimen collection}

2.3.1. Blood: Twenty four hours after the last dose, animals were anaesthetized using ether and venous blood $(3 \mathrm{~mL})$ was collected from the retro-orbital plexus using a capillary glass tube. Samples were then ejected into nonheparinized glass tubes and allowed to clot for $30 \mathrm{~min}$ at $25{ }^{\circ} \mathrm{C}$ after which serum was separated by centrifugation $(600 \mathrm{~g}, 15 \mathrm{~min}, 4$ ${ }^{\circ} \mathrm{C}$ ) and stored at $-20{ }^{\circ} \mathrm{C}$ until analysis.

2.3.2. Organs: Rats were sacrificed by cervical dislocation. Brain and lung of all test animals were excised, washed with ice cold saline and weighed. They are divided into three parts. The first part (about $1 \mathrm{~g}$ ) were wrapped with aluminum foil then kept frozen at $-20^{\circ} \mathrm{C}$ till it was used for estimation of copper content. The second part was wrapped with aluminum foil then kept frozen at $-20^{\circ} \mathrm{C}$ till it was used for DNA extraction. The third part was fixed in $10 \%$ formalin for histopathological and immunohistochemical studies.

\subsection{Biochemical studies:}

2.4.1 Serum malondialdehyde (MDA) level was assayed according to the spectrophotometric method of Ohkawa et al. (1979).

2.4.2 Copper content in the brain and lung was assayed according to (Dry Ashing (Oxidation) method) proposed by Elmer, (1996).

2.5. Qualitative assessment of DNA fragmentation (DNA laddering) in the brain and lung:

It is a qualitative analysis of DNA fragmentation by agarose gel electrophoresis, the presence of DNA ladder was determined according to Wlodek et al. (1991).Tissue samples were coded and analyzed in blind manner for genomic DNA extraction using the commercially available G-spin TM Total DNA Extraction Kit (iNtron bio-tehnology, Seongnam-Si, Gyeonggi-do, Korea).

\subsection{Histopathological study:}

Parts of brain and lung were fixed in 10\% formalin. After fixation, they were embedded in paraffin blocks and processed for the preparation of $5 \mu$ thickness sections. These sections were subjected for hematoxylin and eosin stains (Kiernan, 2001).

\subsection{Immunohistochemical study:}

Immunohistochemical examination was carried out according to the method of Ramos-Vara (2005) using monoclonal antibody kits (USA, ABclonal; Cat. No. ab4051).

\subsection{Statistical analysis:}

Data were analyzed by Statistical Package of Social Science (SPSS), software version 20 (SPSS Inc., 2011). Data were normally distributed and summarized as mean \pm SD (standard deviation). The following tests were used: One way analysis of variance (ANOVA): it was used for comparison between several means. Least significance difference (LSD): it was used for multiple comparisons between groups. Paired t- test: it was used for comparison between two means to test the difference between the two periods of the study. Pearson's Correlation coefficient rank test: it was used to rank different variables against each other in linear correlation which may be positive or negative. Probability ( $\mathrm{P}$ value of $>0.05$ indicates nonsignificant results; $\mathrm{P}$ value $<0.05$ means significant difference, $\mathrm{P}$ value $>0.001$ for highly significant result).

\section{RESULTS}

\subsection{Characterization of $\mathrm{CuO}$ NPs:}

Characterization of $\mathrm{CuO}$ NPs by transmission electron microscopy (TEM) showed that the majority of the $\mathrm{CuO}$ NPs were nearly spherical in shape with different sizes ranging from 4 to $10 \mathrm{~nm}$ (Fig. 1). 


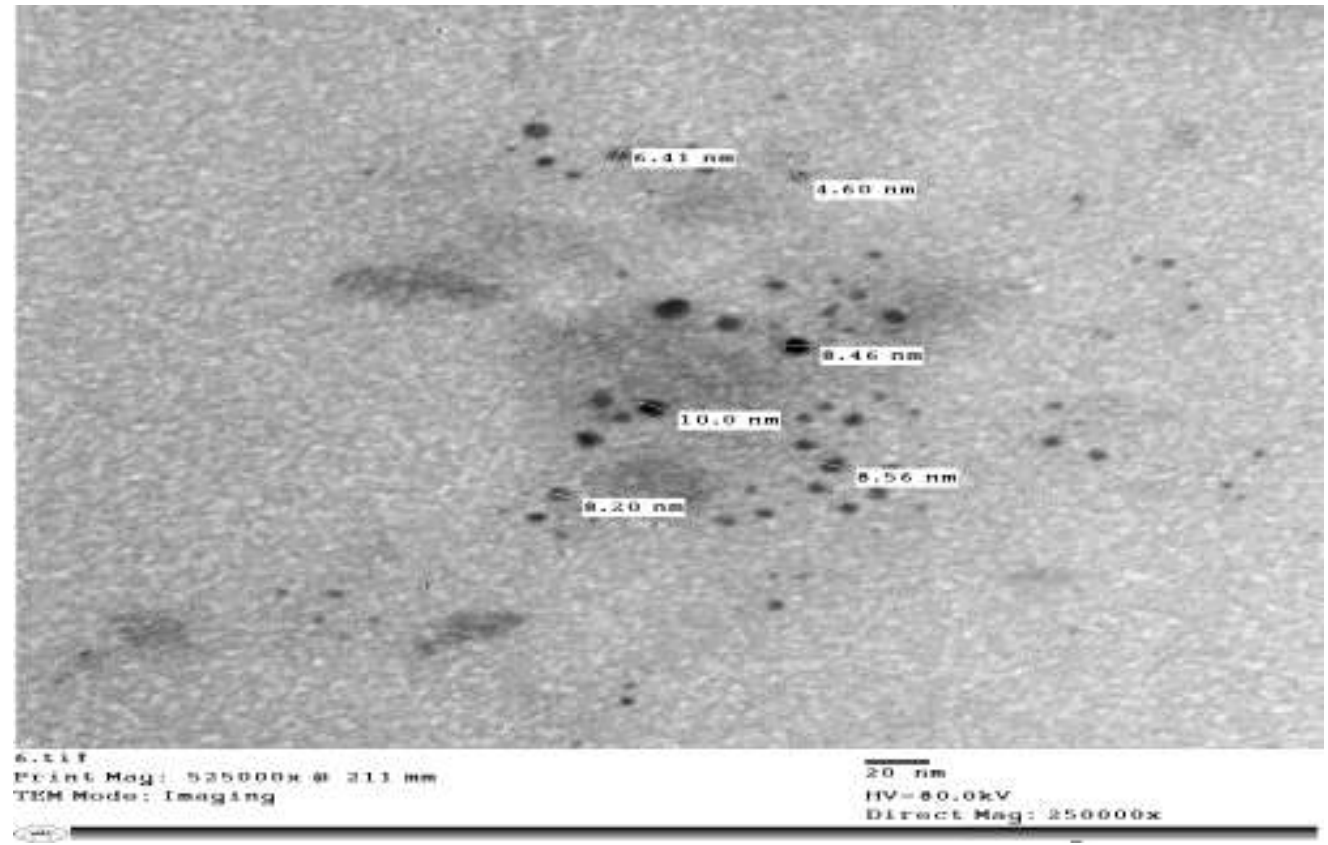

Figure 1: Transmission electron microscopy image of copper oxide nanoparticles.

\subsection{Biochemical results:}

The biochemical parameters of control groups and vitamin $\mathrm{E}$ treated group:

As comparing the laboratory results of serum MDA and copper content in the brain and lung of negative control group (I), positive control group (IIA), positive control group (IIB), vitamin E treated group (III) by ANOVA and Paired t-test, there was no statistically significant difference between them all over the period of the study ( $\mathrm{p}>$ $0.05)$. So, we used negative control group as a standard reference for comparison with other treated groups (Table 1).

Table (1): Statistical comparison among negative control group (I), positive control (IIA) \& (IIB) and vitamin E treated group (III) as regard mean values of serum MDA and copper content in the brain and lung after four \&eight weeks using ANOVA test.

\begin{tabular}{|c|c|c|c|c|c|c|c|}
\hline \multirow[t]{2}{*}{ Groups } & \multirow[t]{2}{*}{ Period } & $\begin{array}{l}\text { Negative } \\
\text { control } \\
\text { (I) }\end{array}$ & $\begin{array}{l}\text { Positive } \\
\text { control } \\
\text { (IIA) }\end{array}$ & $\begin{array}{l}\text { Positive } \\
\text { control } \\
\text { (IIB) }\end{array}$ & $\begin{array}{l}\text { Vitamin E } \\
\text { (III) }\end{array}$ & \multirow[t]{2}{*}{ F } & \multirow[t]{2}{*}{$P$} \\
\hline & & \multicolumn{4}{|c|}{$\begin{array}{c}\text { Mean } \pm \text { SD } \\
n=6\end{array}$} & & \\
\hline \multirow{2}{*}{$\begin{array}{l}\text { Serum malondialdehyde } \\
(\mathrm{nmol} / \mathrm{L})\end{array}$} & 4 weeks & $2.6 \pm 0.8$ & $2.7 \pm 0.7$ & $2.7 \pm 0.8$ & $3.0 \pm 1.0$ & 0.172 & 0.9 \\
\hline & 8 weeks & $3.0 \pm 1.1$ & $3.3 \pm 0.9$ & $2.8 \pm 0.4$ & $2.8 \pm 0.5$ & 0.314 & 0.8 \\
\hline \multirow{2}{*}{$\begin{array}{c}\text { Copper content } \\
\text { in brain } \\
(\mu \mathrm{g} / \mathrm{g})\end{array}$} & 4 weeks & $2.3 \pm 0.5$ & $2.5 \pm 0.3$ & $2.4 \pm 0.8$ & $2.6 \pm 0.7$ & 0.174 & 0.9 \\
\hline & 8 weeks & $2.4 \pm 0.5$ & $2.9 \pm 0.4$ & $3.1 \pm 1.0$ & $2.6 \pm 0.2$ & 0.541 & 0.6 \\
\hline \multirow{2}{*}{$\begin{array}{l}\text { Copper content } \\
\text { in lung } \\
(\mu \mathrm{g} / \mathrm{g})\end{array}$} & 4 weeks & $3.6 \pm 0.6$ & $3.2 \pm 1.0$ & $3.4 \pm 0.9$ & $3.3 \pm 0.7$ & 0.205 & 0.8 \\
\hline & 8 weeks & $3.0 \pm 0.8$ & $2.9 \pm 0.3$ & $3.3 \pm 0.5$ & $2.8 \pm 0.3$ & 0.231 & 0.9 \\
\hline
\end{tabular}

N.B All values are expressed as Mean \pm SD. (SD: standard deviation). $n$ : number (number of rats in each group $=6$ rats). $P$ : $>0.05$ non significant. P: $<0.05$ significant. 
The biochemical parameters of treated

\section{groups:}

- Serum malondialdehyde :

$\mathrm{CuO}$ NPs group showed a highly significant $(\mathrm{p}<0.001)$ increase in mean values of serum MDA when compared to negative control group after four (Table 2) and eight weeks (Table 3).

$\mathrm{CuO}$ NPs +vit. E group showed a highly significant $(\mathrm{p}<0.001)$ improvement when compared with that of $\mathrm{CuO}$ NPs group but still significantly higher than $(\mathrm{p}<0.001)$ negative control group in mean values which indicate partial improvement

- Copper content in the brain and lungs: $\mathrm{CuO}$ NPs group and $\mathrm{CuO}$ NPs +vit. E group showed a highly significant $(\mathrm{p}<0.001)$ increase in mean values of copper content in the brain and lungs when compared to negative control group after four (Table 2) and eight weeks (Table 3).

Table (2): Statistical comparison among negative control (I), $\mathrm{CuO}$ NPs and $\mathrm{CuO}$ NPs +vitamin E groups as regard mean values of serum MDA and copper content in the brain and lungs after four weeks using ANOVA test and LSD test.

\begin{tabular}{|l|l|l|l|l|l|}
\hline Groups & $\begin{array}{l}\text { Negative control } \\
\text { Mean } \pm \mathrm{SD} \\
\mathrm{n}=6\end{array}$ & $\begin{array}{l}\text { CuO NPs } \\
\text { Pean } \pm \mathrm{SD} \\
\mathrm{n}=6\end{array}$ & $\begin{array}{l}\text { CuO NPs } \\
+ \text { Vit. E } \\
\text { Mean } \pm \text { SD } \\
\mathrm{n}=6\end{array}$ & F & P \\
\hline $\begin{array}{l}\text { Serum } \\
\text { malondialdehyde } \\
(\mathrm{nmol} / \mathrm{L})\end{array}$ & $2.6 \pm 0.8^{\mathrm{bc}}$ & $28.0 \pm 5.7^{\mathrm{ac}}$ & $14.0 \pm 2.3^{\mathrm{ab}}$ & 74.2 & $<0.001^{* *}$ \\
\hline $\begin{array}{l}\text { Copper content in } \\
\text { brain } \\
(\mu \mathrm{g} / \mathrm{g})\end{array}$ & $2.3 \pm 0.5^{\mathrm{bc}}$ & $6.6 \pm 0.7^{\mathrm{a}}$ & $5.5 \pm 1.5^{\mathrm{a}}$ & 28.6 & $<0.001^{* *}$ \\
\hline $\begin{array}{l}\text { Copper content in } \\
\text { lung } \\
(\mu \mathrm{g} / \mathrm{g})\end{array}$ & $3.6 \pm 0.6^{\mathrm{bc}}$ & $10.0 \pm 1.2^{\mathrm{a}}$ & $9.7 \pm 1.4^{\mathrm{a}}$ & 58.1 & $<0.001^{* *}$ \\
\hline
\end{tabular}

N.B All values are expressed as Mean \pm SD. (SD: standard deviation).

$\mathrm{n}$ : number (number of rats in each group $=6$ rats). $\mathrm{nmol} / \mathrm{L}=$ nanomole per liter $\mu \mathrm{g} / \mathrm{g}=$ microgram per gram; $* *=$ Highly Significant $(\mathrm{P}<0.001) . \mathrm{a}=$ significant with group $(\mathrm{I}) \quad \mathrm{b}=$ significant with group $(\mathrm{IV}) \quad \mathrm{c}=$ significant with group $(\mathrm{V})$ 
Table (3): Statistical comparison among negative control (I), CuO NPs (IV) and CuO NPs +vitamin $\mathrm{E}(\mathrm{V})$ groups as regard mean values of serum MDA and copper content in the brain and lungs after eight weeks using ANOVA test and LSD test.

\begin{tabular}{|l|l|l|l|l|l|}
\hline & $\begin{array}{l}\text { Negative } \\
\text { control } \\
\text { (I) } \\
\text { Mean } \pm \text { SD } \\
\mathrm{n}=6\end{array}$ & $\begin{array}{l}\text { CuO NPs } \\
\text { (IV) } \\
\text { Mean } \pm \text { SD } \\
\mathrm{n}=6\end{array}$ & $\begin{array}{l}\text { CuO NPs } \\
+ \text { Vit. E } \\
\text { (V) } \\
\text { Mean } \pm \text { SD } \\
\mathrm{n}=6\end{array}$ & F & P \\
\hline $\begin{array}{l}\text { Serum malondialdehyde } \\
(\text { nmol/L) }\end{array}$ & $3.0 \pm 1.1^{\mathrm{bc}}$ & $49.5 \pm 10.9^{\mathrm{ac}}$ & $18.7 \pm 2.1^{\mathrm{ab}}$ & 81.7 & $<0.001^{* *}$ \\
\hline $\begin{array}{l}\text { Copper content in brain } \\
(\mu \mathrm{g} / \mathrm{g})\end{array}$ & $2.4 \pm 0.5^{\mathrm{bc}}$ & $9.1 \pm 1.5^{\mathrm{a}}$ & $7.8 \pm 1.6^{\mathrm{a}}$ & 43.3 & $<0.001^{* *}$ \\
\hline $\begin{array}{l}\text { Copper content in lung } \\
(\mu \mathrm{g} / \mathrm{g})\end{array}$ & $3.0 \pm 1.0^{\mathrm{bc}}$ & $17.3 \pm 2.1^{\mathrm{a}}$ & $16.7 \pm 2.1^{\mathrm{a}}$ & 114.3 & $<0.001^{* *}$ \\
\hline
\end{tabular}

N.B All values are expressed as Mean \pm SD. (SD: standard deviation). $\mathrm{n}$ : number (number of rats in each group $=6$ rats). $\mathrm{nmol} / \mathrm{L}=$ nanomoles per liter $* *=$ Highly Significant $(\mathbf{P}<0.001)$.

$\mu \mathrm{g} / \mathrm{g}=$ microgram per gram $\mathbf{a}=$ significant with group $(\mathrm{I}) \quad \mathbf{b}=$ significant with group $(\mathrm{IV}) \quad \mathrm{c}=\operatorname{significant}$ with group $(\mathrm{V})$

\subsection{Qualitative assessment of DNA fragmentation (DNA laddering) in the brain and lungs:}

Normally, DNA moves as one band on gel. Dispersion of this band means damage of DNA.

Gel electrophoresis of DNA isolated from negative control, positive control (IIA), positive control (IIB) and vitamin E treated groups showed normal DNA bands (lanes2, 3, 4\&5).

Administration of CuO NPs for 4 weeks resulted in moderate shearing of DNA (Lanes 6), and this DNA shearing became more advanced after 8weeks (Lanes 8). Administration of vitamin E along with $\mathrm{CuO}$ NPs for 4 \&8 weeks resulted in mild DNA shearing (Lanes 7\&9) (Fig. 2).

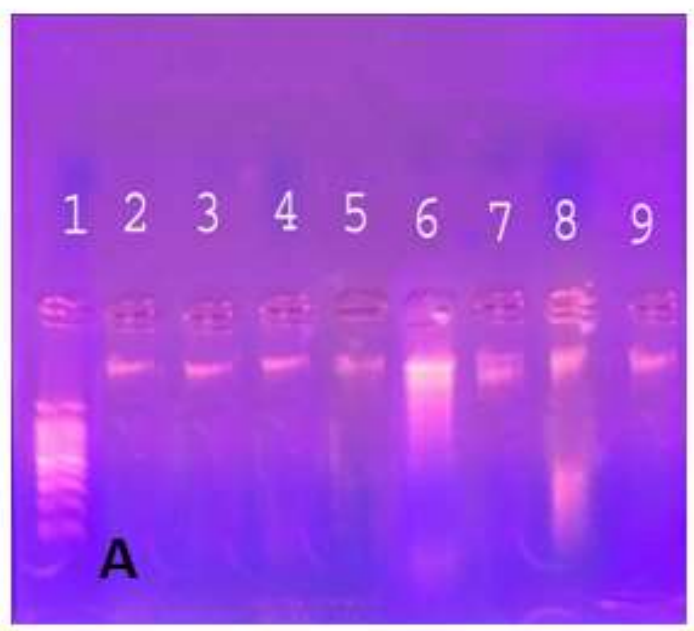

Figure 2: Agarose gel electrophoresis of DNA isolated from rat brain (A) and lung (B). Lane 1: DNA ladder. Lane 2, 3, 4, 5: showing normal DNA band of control groups. Lane 6: showing moderate shearing of DNA of $\mathrm{CuO}$ NPs treated group after 4 weeks. Lane 7: showing mild shearing of DNA of

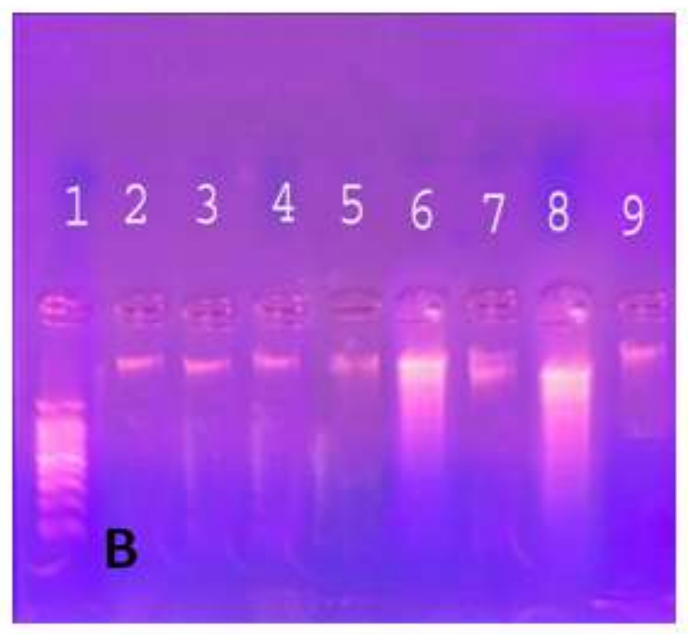

$\mathrm{CuO}$ NPs + vitamin E treated group after 4 weeks. Lane 8: showing advanced shearing of DNA in $\mathrm{CuO}$ NPs treated group after 8 weeks. Lane 9: showing mild shearing of DNA in $\mathrm{CuO} \mathrm{NPs} \mathrm{+} \mathrm{vitamin} \mathrm{E} \mathrm{treated} \mathrm{group}$ after 8 weeks. 


\subsection{Histopathology.}

Light microscopical examination of H\&E stained sections from the hippocampus of the brain of control groups and vitamin $\mathrm{E}$ treated group at 4 weeks and 8 weeks showed that the hippocampus was composed of three layers: molecular, pyramidal and polymorphic. The molecular and polymorphic layers contained few cells while the pyramidal layer was formed of numerous rounded nerve cells containing large vesicular nuclei with prominent nucleoli and pale basophilic cytoplasm (Fig. 3 A).

After 4 weeks of treatment of animals with copper oxide nanoparticles, the hippocampus of the brain of this group showed that the pyramidal layer had many shrunken cells with darkly stained cytoplasm and dark nuclei (Fig. 3 B).

After 8 weeks histopathological changes were more marked and there were numerous shrunken nerve cells of the pyramidal layer with darkly stained cytoplasm and dark nuclei (Fig. 3 C).

After 4 weeks and 8 weeks of administration of vitamin $\mathrm{E}$ with $\mathrm{CuO}$ NPs the hippocampus of the brain tissue showed that the pyramidal layer had rounded nerve cells containing large vesicular nuclei with prominent nucleoli and pale basophilic cytoplasm and minimal shrunken nerve cells with darkly stained cytoplasm and dark nuclei (Fig. 3 D\&E).
Light microscopical examination of $\mathrm{H} \& \mathrm{E}$ stained sections from the lung of control groups and vitamin E treated group at 4 weeks and 8 weeks showed normal spongy histological appearance with numerous alveoli connected together and open into alveolar sacs. They are separated by thin interalveolar septa. Bronchioles and blood vessels were normal (Fig. 4 A).

After 4 weeks of treating animals with copper oxide nanoparticles, stained sections from the lung of this group showed moderate infiltration of inflammatory cells, thickening of interalveolar septa, vacuolation and alveolar congestion (blood cells inside the alveoli) (Fig. 4 B).

After 8 weeks the histopathological changes were more marked and diffuse and there was severe infiltration of inflammatory cells, lymphoid aggregates, exudates, thickening of interalveolar septa and fibrosis (Fig. 4 C).

After 4 weeks of administration of vitamin E with $\mathrm{CuO}$ NPs the lung tissue showed conserved normal structure with mild infiltration of inflammatory cells and some congested blood vessels (Fig. 4 D).

After 8 weeks of administration of vitamin $\mathrm{E}$ with $\mathrm{CuO}$ NPs there was moderate infiltration of inflammatory cells and thickening of interalveolar septa (Fig. 4 E). 



Figure 3: photomicrographs of sections of brain of adult male albino rats. (A) control group showing that the pyramidal layer was formed of numerous rounded nerve cells containing large vesicular nuclei (curved arrow) with prominent nucleoli (arrow) and pale basophilic cytoplasm (arrow head) (B\&C) CuO NPs group after $4 \& 8$ weeks showing that the pyramidal layer had many shrunken cells (arrow) with darkly stained cytoplasm and dark nuclei (D\&E) CuO NPs + vitamin E group after $4 \& 8$ weeks showing that the pyramidal layer had rounded nerve cells (arrow head) containing large vesicular nuclei with prominent nucleoli and pale basophilic cytoplasm and minimal shrunken nerve cells (arrow) with darkly stained cytoplasm and dark nuclei (H\&E X400). 

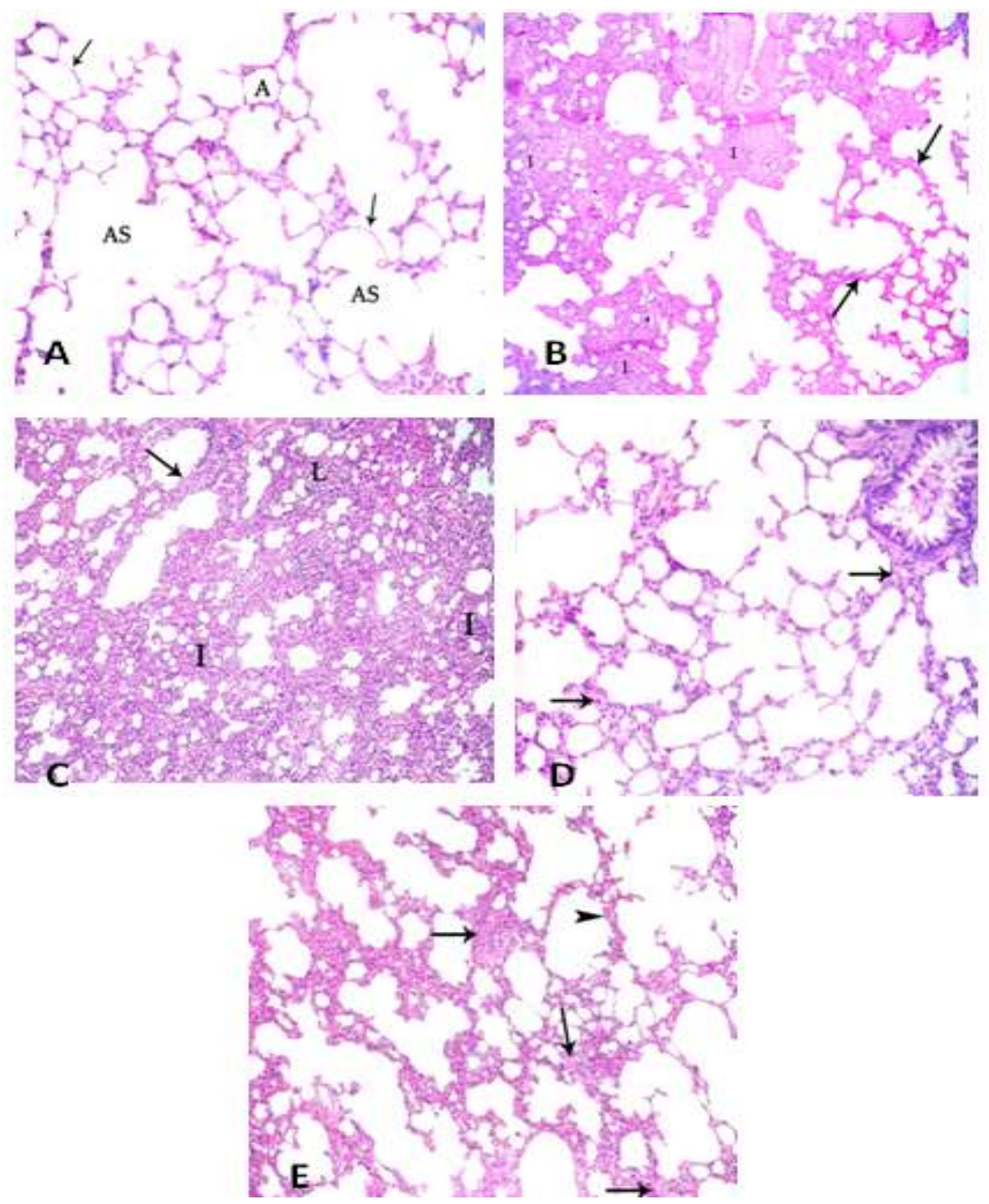

Figure 4: photomicrographs of sections of lung of adult male albino rats. (A) control group showing: Normal spongy histological appearance with numerous alveoli (A) connected together and opened into alveolar sacs (AS) and separated by thin interalveolar septa (arrow) (B) $\mathrm{CuO}$ NPs group after 4 weeks showing moderate infiltration of inflammatory cells (I) and thickening of interalveolar septa (arrow) (C) $\mathrm{CuO}$ NPs group after 8 weeks showing severe infiltration of inflammatory cells (I), lymphoid aggregates (L) and thickening of interalveolar septa (arrow) (D) $\mathrm{CuO}$ NPs + vitamin E group after 4 weeks showing mild infiltration of inflammatory cells (arrow) (E) $\mathrm{CuO} \mathrm{NPs}+$ vitamin $\mathrm{E}$ group after 8 weeks showing moderate infiltration of inflammatory cells (arrow) and thickening of interalveolar septa (arrow head) (H\&E X200).

3.5. Immunohistochemical results (light microscopic detection of Caspase-3):

Immunohistochemical examination of the hippocampus of the brain of control groups showed negative caspase 3 immuno reactivity in the cytoplasm of nerve cells of the pyramidal layer at both 4 and 8 weeks (Fig. 5 A).

$\mathrm{CuO}$ NPs treated group at 4 weeks showed moderate positive caspase-3 immunoreactivity in the cytoplasm of nerve cells of the pyramidal layer of the 
hippocampus compared to control group (Fig. 5 B). $\mathrm{CuO}$ NPs treated group at 8 weeks showed strong positive caspase-3 immunoreactivity in the cytoplasm of nerve cells of the pyramidal layer of the hippocampus compared to control group (Fig. 5 C). Administration of vitamin $\mathrm{E}$ with $\mathrm{CuO}$ NPs for 4 weeks \& 8 weeks revealed weak positive caspase 3 immuno reactivity in the cytoplasm of nerve cells of the pyramidal layer (Fig. 5 D\&E).

Immunohistochemical examination of the lung of control groups showed negative caspase 3 immuno reactivity in the cytoplasm of alveolar cells at both 4 and 8 weeks (Fig. 6 A).

$\mathrm{CuO}$ NPs treated group at 4 weeks showed moderate positive caspase-3 immunoreactivity in the cytoplasm of alveolar cells compared to control group (Fig. 6 B). $\mathrm{CuO}$ NPs treated group at 8 weeks showed strong positive caspase-3 immunoreactivity in the cytoplasm of alveolar cells compared to control group (Fig. 6 C). Administration of vitamin $\mathrm{E}$ with $\mathrm{CuO}$ NPs for 4 weeks \& 8 weeks revealed weak positive caspase 3 immuno reactivity in the cytoplasm of alveolar cells (Fig. 6 D\&E).


Figure 5: Photomicrographs of immunohistochemical staining of caspase-3 of the brain sections of adult male albino rats. (A) Control group showed negative caspase-3 
immunoreactivity in cytoplasm of nerve cells of the pyramidal layer of the hippocampus (arrow). (B) $\mathrm{CuO}$ NPs treated group at 4 weeks showed moderate positive caspase- 3 immunoreactivity in the cytoplasm of nerve cells of the pyramidal layer of the hippocampus (arrow) (C) CuO NPs treated group at 8 weeks showed strong positive caspase-3 immunoreactivity in the cytoplasm

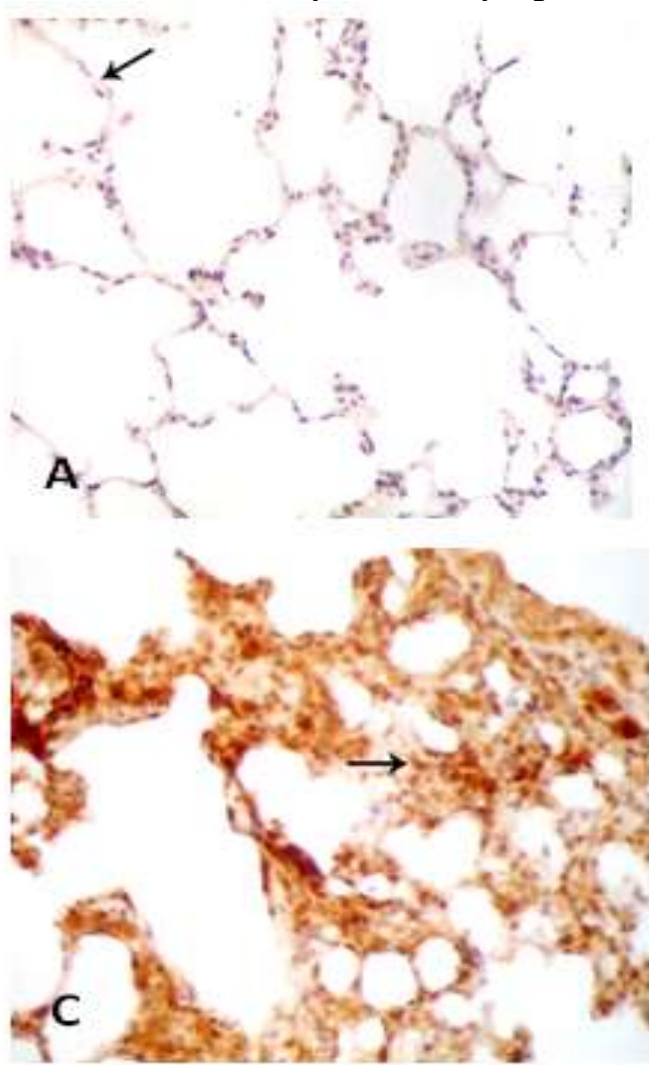

of nerve cells of the pyramidal layer of the hippocampus (arrow) (D\&E) $\mathrm{CuO}$ NPs + vitamin $\mathrm{E}$ treated group after $4 \& 8$ weeks showed weak positive caspase-3 immunoreactivity in the cytoplasm of nerve cells of the pyramidal layer of the hippocampus

(arrow)

\section{(Immunohistochemical x400).}
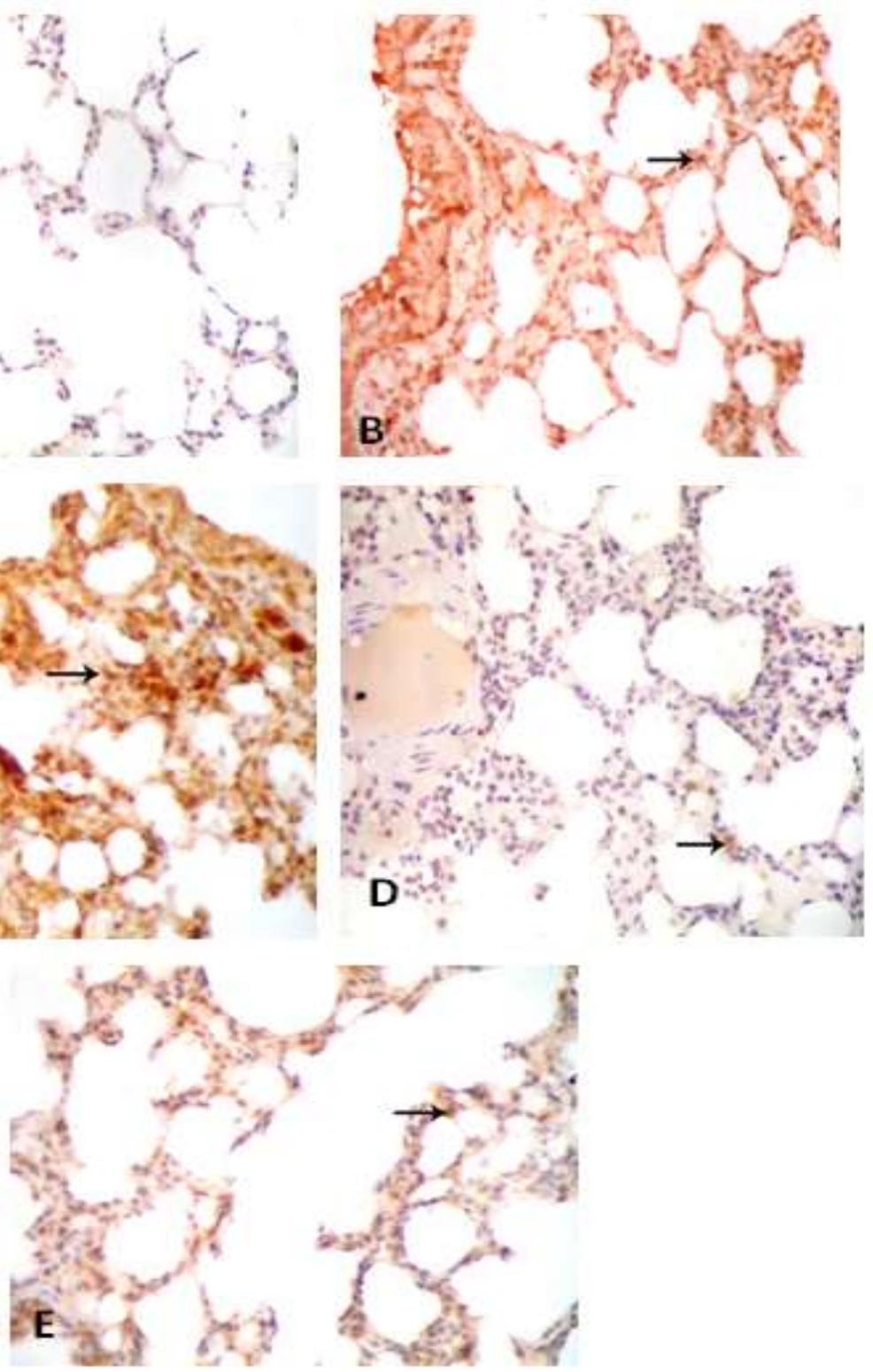

Figure 6: Photomicrographs of immunohistochemical staining of caspase- 3 in the lung sections of adult male albino rats. (A) Control group showing negative caspase-3 immunoreactivity in cytoplasm of alveolar cells (arrow). (B) CuO NPs treated group at 4 weeks showed moderate positive caspase-3 immunoreactivity in the cytoplasm of alveolar cells (arrow) (C) CuO NPs treated group at 8 weeks showed strong positive caspase-3 immunoreactivity in the cytoplasm of alveolar cells (arrow) (D\&E) $\mathrm{CuO}$ NPs + vitamin E treated group at $4 \& 8$ weeks showed weak positive caspase-3 immunoreactivity in the cytoplasm of alveolar cells (arrow) (Immunohistochemical x400). 


\section{DISCUSSION}

Characterization of $\mathrm{CuO}$ NPs by transmission electron microscopy (TEM) showed that the majority of them were nearly spherical in shape with different sizes ranging from 4 to $10 \mathrm{~nm}$. The physicochemical properties of the NPs such as size, shape, high specific surface area and its solubility play an important role in its toxicity (EL Shemy et al., 2017).

The current study showed that the administration of $\mathrm{CuO}$ NPs in rats at a dose of $250 \mathrm{mg} / \mathrm{kg}$ body weight for 8 weeks induced pulmonary toxicity, neurotoxicity, oxidative stress and genotoxic effects and administration of vitamin $E$ with $\mathrm{CuO}$ NPs offers some protection against their damaging effect.

As regarding serum MDA, there was increase in serum MDA level in CuO NPs and $\mathrm{CuO} \mathrm{NPs}+$ vitamin $\mathrm{E}$ treated groups when compared with negative control groups, also there was increase in MDA level of CuO NPs treated group at 8 weeks when compared with their mean values at 4 weeks. These results were consistant with Elhussainy and ElShourbagy (2015) who found a significant increase in MDA after administration of $\mathrm{CuO}$ NPs (40-56 nm) in a dose of $10 \mathrm{mg} / \mathrm{kg}$ daily for two weeks by intraperitoneal injection in rats and explained liver and kidney damage caused by $\mathrm{CuO}$ NPs by oxidative stress and lipid peroxidation as excessive nano copper accumulation in hepatocytes or nephrocytes would inevitably result in mitochondrial failure and cell death. Also, Alarifi et al. (2013) stated that oxidative stress has been cited to be one of the most important mechanisms of toxicity related to nanoparticles exposure. This has been attributed to their small size and large surface area that are generally thought to produce ROS and oxidative stress. The $\mathrm{CuO}$ NPs were found to be capable of generating intracellular ROS which can oxidize and reduce macromolecules (DNA, lipids, and proteins) resulting in significant oxidative damage to cells.

After administration of vitamin $\mathrm{E}$, there was decrease in serum MDA level in $\mathrm{CuO}$ NPs +vitamin E group when compared with $\mathrm{CuO}$ NPs group after four and eight weeks which means protective effect of vitamin $\mathrm{E}$ againstCuO NPs induced oxidative stress.

Bharrhan et al. (2010) explained the effect of vitamin $\mathrm{E}$ by its direct free radical scavenging property and preserving cellular integrity, it can protect against oxidative stress and lipid peroxidation which induce organ damage. The results of this study passed in parallel with those of Elhussainy and El-Shourbagy (2015) who found that pretreatment with Multivitamin Complex (vitamins E, C and A) in rats received $\mathrm{CuO}$ NPs $40-56 \mathrm{~nm}$ in a dose of $10 \mathrm{mg} / \mathrm{kg}$ daily for two weeks by intraperitoneal injection"

significantly decreased the blood and tissues levels of MDA when compared with nano $\mathrm{CuO}$ toxic rats.

As regarding copper content in the brain and lungs there was increase in copper content in the brain and lungs after $4 \& 8$ weeks in $\mathrm{CuO}$ NPs and $\mathrm{CuO}$ NPs + vitamin $\mathrm{E}$ treated groups when compared with negative control group. Also there increase in copper content in the brain and lungs in $\mathrm{CuO}$ NPs and $\mathrm{CuO}$ NPs + vitamin $\mathrm{E}$ treated groups after eight weeks when compared with values after four weeks. These results means that administration of $\mathrm{CuO}$ NPs resulted in increased copper deposition in the brain and lungs which was time dependant. Bulcke and Dringen (2016) explained that $\mathrm{CuO}$ NPs application had led to substantial cellular copper accumulation as they are likely to enter astrocytes by endocytotic mechanisms. Also extracellular liberation of copper ions has been suggested to be involved in the copper accumulation observed in glial cells after exposure to $\mathrm{CuO}$ NPs (Joshi et al., 2016). The reported toxicity of $\mathrm{CuO}$ NPs to brain cells is most likely mediated by accelerated ROS production and oxidative damage (Bulcke et al., 2017). Karmakar et al. (2014) explained the neurotoxicity induced by $\mathrm{CuO}$ NPsas they are capable of crossing the BBB due to their nano level size. Copper NPs can cause BBB dysfunction, swelling of astrocytes, and neuronal degeneration once introduced into the blood stream. The results of this study passed in parallel with those of Bai et al. (2014) who found that copper nanoparticles 
could enter the brain after intranasal instillation of copper nanoparticles $(23.5 \mathrm{~nm})$ for 21 days, the $\mathrm{Cu}$ concentrations were significantly higher in all tested sub brain regions in treated group of animals received a dose of 10 and $40 \mathrm{mg} / \mathrm{kg}$ than in the control and this excess copper had led to damage of neurons in cerebral cortex and hippocampus. Also, Gosens et al. (2016) studied organ burden and pulmonary toxicity of $\mathrm{CuO}$ NPs after short-term inhalation exposure and found that repeated exposures to $\mathrm{CuO}$ NPs $(15-20 \mathrm{~nm})$ for 5 consecutive days resulted in increase in the measured lung burden of copper and presence of lung inflammation.

$\mathrm{CuO}$ NPs induced genotoxic effect as reflected by moderate shearing of DNA after 4 weeks of exposure and this DNA shearing became more advanced after 8weeks. This was in accordance with significant increase in serum MDA and copper content in the brain and the lung. Singh et al. (2009) explained the genotoxicity of $\mathrm{CuO}$ NPs as the intracellular small $\mathrm{CuO}$ NPs can enter into nucleus by nucleopore or gain access with the nucleus lysed during cell division which may lead to inhibition of transcription and translation machinery, damage of genetic material by interacting with DNA or DNA-related proteins.The observations of present study were consistent with an in vitro study by Perreault et al. (2012) who investigated the genotoxic effects of $\mathrm{CuO}$ NPs using the N2A mouse neuroblastoma cell lines. Agarose gel electrophoresis of total DNA extracted from these cells after $24 \mathrm{~h}$ of $\mathrm{CuO} \mathrm{NP}$ treatments indicated the presence of DNA fragmentation. They explained the DNA damage by two pathways: via direct association with DNA strands for NPs of small diameter or mediated by oxidative stress. It may occur via oxidation by products such as malondialdehyde (MDA), a mutagenic and carcinogenic by product of lipid peroxidation. Another in vitro study was done by Ahamed et al. (2010) who found that $\mathrm{CuO}$ NPs have damaging effects on DNA integrity in human lung epithelial cells A549 exposed to $\mathrm{CuO}$ NPs $(50 \mathrm{~nm})$ in the concentration range of $10-50 \mu \mathrm{g} / \mathrm{ml}$.

Administration of vitamin $\mathrm{E}$ with $\mathrm{CuO}$ NPs for $4 \& 8$ weeks resulted in mild DNA shearing. This was in accordance with significant decrease in serum MDA which means that decreased oxidative stress by vitamin $\mathrm{E}$ had led to decrease DNA damage. Thit et al. (2015) suggested that the main cause of DNA damage due to $\mathrm{CuO}$ NPs was ROS generation, so DNA damage could be reduced significantly by increasing the cell's oxidative defense. The results of this study passed in parallel with those of Privalova et al. (2014) who demonstrated that a bio protective complex comprising a multivitamin and multimineral preparation including vitamin $\mathrm{E}$ attenuated systemic toxicity and genotoxicity of $\mathrm{CuO}$ NPs.

$\mathrm{CuO}$ NPs induced a neurotoxic effect as reflected by presence of many shrunken nerve cells with darkly stained cytoplasm and dark nuclei in the pyramidal layer of the hippocampus. These results passed in parallel with those of Bai et al. (2014) who studied the effects of intranasal instillation of copper nanoparticles $(23.5 \mathrm{~nm})$ for 21 days at a dose of 10 and $40 \mathrm{mg} / \mathrm{kg}$. The hippocampus of the brain showed damaged neurons which have shrunken cell bodies, a deeply stained pyknotic nucleus with triangular or elongated profile and the nucleoli disappear, as well as a widened gap between the nucleus and the cell membrane. They explained these changes as nanoparticles deposited for a long term in the brain may contribute to cellular interaction and free radical production which could cause brain damage. Various studies have explained the resulting cytotoxicity due to the initial induction of lipid peroxidation of the mitochondrial membrane by a metal which might cause decoupling of oxidative phosphorylation, disruption of electron transport, and a decrease in mitochondrial membrane potential. It has been suggested that neurodegenerative process associated with copper overload may be due to the mitochondrial damage, increased production of ROS, and failure of the antioxidant defense mechanisms (Prabhu et al., 2010). The results of the present study were supported by Privalova et al. (2014) who studied the effect of $\mathrm{CuO}$ NPs $(20 \pm 10 \mathrm{~nm})$ injected intraperitoneally to rats at a dose of $10 \mathrm{mg} / \mathrm{kg}$ three times a week up to 19 injections. The 
brain showed several histopathological changes in the form of poorly stained neuron nuclei, with an indistinct membrane, the nucleoli are pyknotic, or often absent.

Also, $\mathrm{CuO}$ NPs induced a pulmonary toxic effect as reflected by presence of moderate infiltration of inflammatory cells, thickening of interalveolar septa, vacuolation and alveolar congestion after 4 weeks. After 8 weeks, the histopathological changes were more marked and diffuse and there was severe infiltration of inflammatory cells, lymphoid aggregates, exudates, thickening of interalveolar septa and fibrosis. These results indicate that $\mathrm{CuO}$ NPs have inflammatory potentials that lead to irreversible chronic lesions such as fibrosis or granulomas. Thickening of interalveolar septa induced by $\mathrm{CuO}$ NPs in this study could be explained by the interstitial collagen fiber deposition and marked inflammatory infiltration. Adamcakova-Dodd et al. (2011) attributed lung histopathological changes observed in in-vivo studies to "overload phenomenon" when alveolar macrophages have an impaired ability to remove particles. Considering this overload phenomenon, any insoluble particle of low toxicity can cause chronic pulmonary inflammation, lung fibrosis, or even tumors at a high enough dose. Excess copper intake has been shown to be toxic and induce pulmonary inflammation characterized by increased neutrophils. The increased inflammatory response of copper is proposed to be associated with the nanoparticle size and increased ion concentration produced from the dissolving nanoparticles in vivo (Pettibone et al., 2008). Lai et al. (2018) explained pulmonary fibrosis induced by $\mathrm{CuO}$ NPs as $\mathrm{CuO}$ NPs exposure promoted collagen accumulation and expression of the progressive fibrosis marker in the lung tissues and this provide novel evidence that there is an urgent need to prevent the adverse effects of $\mathrm{CuO}$ NPs in the human respiratory system. These results passed in parallel with those of Doudi and Setorki (2014) who studied the effects of intraperitoneal injection of different doses $(10,100$, and $300 \mathrm{mg} / \mathrm{kg})$ of $\mathrm{CuO}$ NPswith $10-15 \mathrm{~nm}$ diameters on the lung for 14 days and found that treatment groups receiving 100 and $300 \mathrm{mg} / \mathrm{kg} \quad \mathrm{CuO}$ nanoparticles showing air sac wall thickening and increased fibrous tissues.

Administration of vitamin $\mathrm{E}$ with $\mathrm{CuO}$ NPs showed some improvement in histopathological changes in brain and lung. These results were consistant with Elhussainy and El-Shourbagy (2015) who found that pretreatment with Multivitamin Complex (vitamins $\mathrm{E}, \mathrm{C}$ and $\mathrm{A}$ ) in $\mathrm{CuO}$ induced toxic rats improved hepatic and renal structures by histopathological examination and suggested that Multivitamin Complex has potential protective role against $\mathrm{CuO}$ NPs induced toxicity by an antioxidant mechanism.

The immunohistochemical examination revealed that the brain and lung of $\mathrm{CuO}$ NPs treated group after 4 weeks showed moderate positive caspase 3 immuno reactivity in the cytoplasm of the nerve cells of the pyramidal layer of the hippocampus of the brain and the cytoplasm of alveolar cells of lungs and it was markedly increased after 8 weeks. Chibber and Shanker (2017) explained the mechanism for activation of apoptosis by $\mathrm{CuO}$ NPs by a mitochondrial-mediated pathway which is initiated by ROS generation. It results in destruction of the mitochondrial membrane via ROS. It is likely that activation of apoptosis by mitochondrial membrane damage results in a cascade which leads to the activation of caspase 3 . Hosseini et al. (2014) reported that excess of deposited $\mathrm{Cu}$ increases lipid peroxidation, protein oxidation, mitochondrial membrane potential decline and cytochrome $\mathrm{c}$ expulsion that start cell death signaling. The results of the present study were supported by An et al. (2012) who found that the caspase 3 content was significantly increased in the hippocampus of $\mathrm{CuO}$ NPs group (received $\mathrm{CuO}$ NPs (10-70 $\mathrm{nm})$ at a dose of $0.5 \mathrm{mg} / \mathrm{kg} /$ day via intraperitoneal injection and given once a day over a period of 14 consecutive days) compared to that in control group. In an in vitro study carried out by Alarifi et al. (2013), a significant increase in caspase 3 activity, indicating apoptosis was observed during incubation of $\mathrm{CuO}$ NPs with human skin keratinocytes cells. 
Administration of vitamin $\mathrm{E}$ with $\mathrm{CuO}$ NPs for 4 weeks revealed partial decreased caspase 3 immuno reactivity in the cytoplasm of nerve cells of pyramidal layer of the hippocampus of left cerebral hemisphere of the brain and the cytoplasm of alveolar cells of lungs. More diminished immuno reactivity was demonstrated after 8 weeks. Copper overload induced a prooxidative condition in brain, increasing cholesteryl esters, modifying the fatty acyl pattern of complex lipids and causing alterations in proteins. These changes are related to the activation of neuronal apoptosis that may have important implications in $\mathrm{Cu}$ associated brain diseases. Large number of studies indicates the role of oxidants in developing distinct pathological consequences promoting and propagating oxidative injuries leading to irreversible degeneration in brain (Mazdeh et al., 2016). So vitamin E was used which known as a powerful antioxidant to combat this oxidative effect.

\section{CONCLUSIONS AND RECOMMENDATIONS}

$\mathrm{CuO}$ NPs oral administration induced time dependant toxic effects in the form of oxidative stress, DNA damage, histopathological changes in the brain and lung and vitamin $\mathrm{E}$ administration with $\mathrm{CuO}$ NPs offers protection against their damaging effect.

\section{Conflicts of interest}

There are no conflicts of interest to declare.

\section{REFERENCES}

Adamcakova-Dodd, A., Thorne, P. S. and Grassian, V. H. (2011): In Vivo Toxicity Studies of Metal and Metal Oxide Nanoparticles. In: Handbook of Systems Toxicology, Cascinao, D. A. and Sahu, S. C. (eds.), John Wiley \& Sons, Ltd. pp: 803-834.

Ahamed, M., Siddiqui, M. A., Akhtar, M. J., Ahmad, I., Pant, A. B. and Alhadlaq, H. A. (2010): Genotoxic potential of $\mathrm{CuO}$ NPsin human lung epithelial cells. Biochemical and Biophysical Research Communications, 396(2): 578-583.

Ahamed, M., Alhadlaq, H. A., Khan, M. A., Karuppiah, P. and Al-Dhabi, N. A. (2014): Synthesis, characterization, and antimicrobial activity of copper oxide nanoparticles. Journal of Nanomaterials, 2014: 17.

Alarifi, S., Ali, D., Verma, A., Alakhtani, S. and Ali, B. A. (2013): Cytotoxicity and genotoxicity of $\mathrm{CuO}$ NPsin human skin keratinocytes cells. International Journal of Toxicology, 32(4): 296-307.

An, L., Liu, S., Yang, Z. and Zhang, T. (2012): Cognitive impairment in rats induced by nano- $\mathrm{CuO}$ and its possible mechanisms. Toxicology Letters, 213(2): 220-227.

Bai, R., Zhang, L., Liu, Y., Li, B., Wang, L., Wang, P., Autrupc, H., Beer, C. and Chen, C. (2014): Integrated analytical techniques with high sensitivity for studying brain translocation and potential impairment induced by intranasally instilled copper nanoparticles. Toxicology Letters, 226(1): 7080.

Bharrhan, S., Chopra, K. and Rishi, P. (2010): Vitamin E supplementation modulates endotoxin-induced liver damage in a rat model. American Journal of Biomedical Sciences, 2(1), 51-62.

Bulcke F., Dringen R. and Scheiber I. F. (2017): Neurotoxicity of Copper. In: Neurotoxicity of Metals, Aschner, M. and Costa, L. (eds.), vol. 18. Springer, Cham, pp: 313-343.

Bulcke, F. and Dringen, R. (2016): Handling of copper and CuO NPsby astrocytes. Neurochemical Research, 41(1-2): 33-43.

Chibber, S. and Shanker, R. (2017): Can $\mathrm{CuO}$ nanoparticles lead to epigenetic regulation of antioxidant enzyme system? Journal of Applied Toxicology, 37(1), 84-91. Cho, W. S., Duffin, R., Thielbeer, F., Bradley, M., Megson, I. L., MacNee, W., Poland, C. A., Tran, C. L. and Donaldson, K. (2012): Zeta potential and solubility to toxic ions as mechanisms of lung inflammation caused by metal/metal oxide nanoparticles. Toxicological Sciences, 126(2): 469-477.

Doudi, M. and Setorki, M. (2014): Acute effect of nano-copper on liver tissue and function in rat. Nanomedicine Journal, 1(5): 331-338.

Elhussainy, E. M. A. and El-Shourbagy, S. (2015): Protective effect of Multivitamin 
Complex on $\mathrm{CuO} \mathrm{NPs}($ nanoCuO) induced toxicity in rats. Bulletin Egyptian Society for Physiological Sciences 34 (3): 404-418.

Elmer, P. (1996): Analytical methods for atomic absorption spectroscopy. USA: The Perkin-Elmer Corporation.

EL Shemy, M.A.; Azab, N.I. and Salim, R.F. (2017): Zinc oxide nanoparticles: the hidden danger. International Journal of Biochemistry and Molecular Biology 2: 1-9.

Gaetke, L. M. and Chow, C. K. (2003): Copper toxicity, oxidative stress, and antioxidant nutrients. Toxicology, 189(1-2): 147-163.

Gosens, I., Cassee, F. R., Zanella, M., Manodori, L., Brunelli, A., Costa, A.L., Bokkers, B. G., de Jong, W. H., Brown, D., Hristozov, D. and Stone, V. (2016): Organ burden and pulmonary toxicity of nano-sized copper (II) oxide particles after short-term inhalation exposure. Nanotoxicology, 10(8): 1084-1095.

Grigore, M. E., Biscu, E. R., Holban, A. M., Gestal, M. C. and Grumezescu, A. M. (2016): Methods of synthesis, properties and biomedical applications of $\mathrm{CuO}$ nanoparticles. Pharmaceuticals, 9(4): 75.

Hosseini, M. J., Shaki, F., Ghazi-Khansari, M. and Pourahmad, J. (2014): Toxicity of copper on isolated liver mitochondria: impairment at complexes I, II, and IV leads to increased ROS production. Cell Biochemistry and Biophysics, 70(1): 367-381.

Ingle, A. P., Duran, N. and Rai, M. (2014): Bioactivity, mechanism of action, and cytotoxicity of copper-based nanoparticles: A review. Applied Microbiology and Biotechnology, 98(3): 1001-1009.

Joshi, A., Rastedt, W., Faber, K., Schultz, A. G., Bulcke, F. and Dringen, R. (2016): Uptake and toxicity of CuO NPsin C6 glioma cells. Neurochemical Research, 41(11): 30043019.

Kaewamatawong, T. Kawamura, N., Okajima, M., Sawada, M., Morita, T. and Shimada, A. (2005): Acute pulmonary toxicity caused by exposure to colloidal silica: particle size dependent pathological changes in mice. Toxicologic Pathology, 33(7): 745751.
Karmakar, A., Zhang, Q. and Zhang, Y. (2014): Neurotoxicity of nanoscale materials. Journal of Food and Drug Analysis, 22(1): 147-160.

Kiernan, J. (2001): Histological and Histochemical Methods. In: Theory and Practice (3rd ed.), MacMillan, Oxford, Boston, Johannsbury, New Delhi. pp: 111113 and $150-153$.

Lai, X., Zhao, H., Zhang, Y., Guo, K., Xu, Y., Chen, S. and Zhang, J. (2018): Intranasal delivery of $\mathrm{CuO}$ NPsinduces pulmonary toxicity and fibrosis in C57BL/6 mice. Scientific Reports, 8(1): 4499.

Lewinski, N., Colvin, V. and Drezek, R. (2008): Cytotoxicity of Nanoparticles. Small, 4(1): 26 - 49.

Mazdeh, M., Rahiminejad, M. E., Nili-

Ahmadabadi, A. and Ranjbar, A. (2016):

Neurological disorders and oxidative toxic stress: A role of metal nanoparticles.

Jundishapur Journal of Natural

Pharmaceutical Products, 11(1): 1-7.

Ogutcu, A., Uzunhisarcikli, M., Kalender, S., Durak, D., Bayrakdar, F. and Kalender, Y. (2006): The effects of organophosphate insecticide diazinon on malondialdehyde levels and myocardial cells in rat heart tissue and protective role of vitamin E. Pesticide Biochemistry and Physiology, 86(2): 93-98.

Ohkawa, H., Ohishi, N. and Yagi, K. (1979): Assay for lipid peroxides in animal tissues by thiobarbituric acid reaction. Analytical Biochemistry, 95 (2): 351- 358.

Perreault, F., Melegari, S. P., da Costa, C. H., Rossetto, A. L. D. O. F., Popovic, R. and Matias, W. G. (2012): Genotoxic effects of $\mathrm{CuO}$ NPsin Neuro 2A cell cultures. Science of the Total Environment, 441: 117124.

Pettibone, J. M., Adamcakova-Dodd, A., Thorne, P. S., O'Shaughnessy, P. T., Weydert, J. A. and Grassian, V. H. (2008): Inflammatory response of mice following inhalation exposure to iron and copper nanoparticles. Nanotoxicology, 2(4): 189-204. Prabhu, B. M., Ali, S. F., Murdock, R. C., Hussain, S. M. and Srivatsan, M. (2010): Copper nanoparticles exert size and concentration dependent toxicity on 
somatosensory neurons of rat. Nanotoxicology, 4(2): 150-160.

Privalova, L. I., Katsnelson, B. A., Loginova, N. V., Gurvich, V. B., Shur, V. Y., Valamina, I. E., Makeyev, O. H., Sutunkova, M. P., Minigalieva, I. A., Kireyeva, E. P. and Rusakov, V. O. (2014): Subchronic toxicity of $\mathrm{CuO}$ NPsand its attenuation with the help of a combination of bioprotectors. International Journal of Molecular Sciences, 15(7):12379-12406.

Ramos-Vara, J. A. (2005): Technical aspects of immunohistochemistry. Veterinary Pathology, 42(4): 405 - 426.

Safety data sheet according to Regulation (EC) copper Oxide Nanoparticles. SIGMAALDRICH [Web page] [2014] Available at : (URL:http://www.sigmaaldrich.com/MSDS/ MSDS/DisplayMSDSPage.do?country=EG\&l anguage $=$ en $\&$ productNumber $=544868 \&$ brand $=$ ALDRICH\&PageToGoToURL $=$ http $\% 3 \mathrm{~A} \%$ 2F\%2Fwww.sigmaaldrich.com $\% 2$ Fcatalog $\%$ 2Fproduct $\% 2$ Faldrich $\% 2$ F544868\%3Flang\% 3Den. Access date [Aug (29th/2015)].

Singh, M., Kaur, P., Sandhir, R. and Kiran, R. (2008): Protective effects of vitamin $\mathrm{E}$ against atrazine-induced genotoxicity in rats. Mutation Research/Genetic Toxicology and Environmental Mutagenesis, 654(2): 145-149.
Singh, N., Manshian, B., Jenkins, G. J., Griffiths, S. M., Williams, P. M., Maffeis, T. G., Wright, C. J. and Doak, S. H. (2009): NanoGenotoxicology: the DNA damaging potential of engineered nanomaterials. Biomaterials, 30(23-24): 38913914.

SPSS Inc (2011): SPSS for windows, version 20.0. Chicago, SPSS Inc. http://www.unimunester.de/imperia/md/conte $\mathrm{nt} / \mathrm{ziv} /$ service/software/spss/handbuecher/engl isch/spss_brief_guide_20.0.pdf.

Thit, A., Selck, H. and Bjerregaard, H. F. (2015): Toxic mechanisms of $\mathrm{CuO}$ NPsin epithelial kidney cells. Toxicology in Vitro, 29(5): 1053-1059.

Wlodek, D., Banath, J. and Olive, P. L. (1991): Comparison between pulsed-field and constant-field gel electrophoresis for measurement of DNA double-strand breaks in irradiated Chinese hamster ovary cells. International Journal of Radiation Biology, 60(5): 779-790.

Yousef, M. I., Awad, T. J. and Mohamed, E.H. (2006): Deltamethrin-induced oxidative damage and biochemical alterations in rat and its attenuation by vitamin E. Toxicology, 227(3): 240-247. 
دراسة السمية الرئوية والعصبية والجينية المزمنة قصيرة الأمد لجزيئات أكسيد النحاس متناهية الدقة والدور



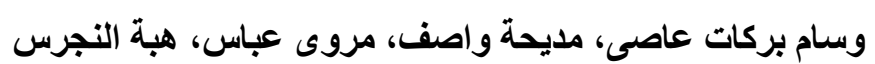

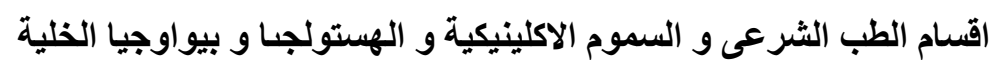

$$
\text { كلية الطب- جامعة الزقازيق }
$$

تستخدم جزيئات أكسبد النحاس متناهية الاقة على نطاق واسع كأثباه للموصلات وفي الأدوية



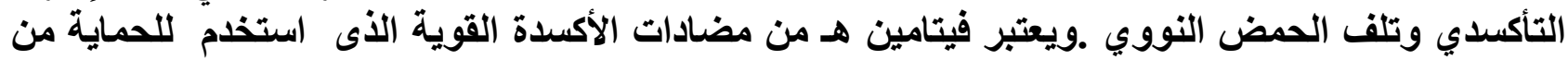

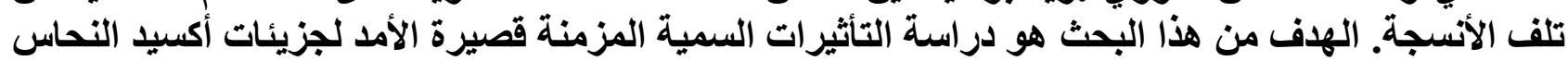

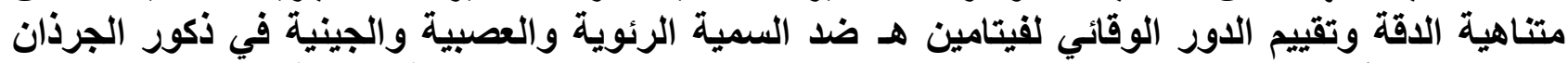



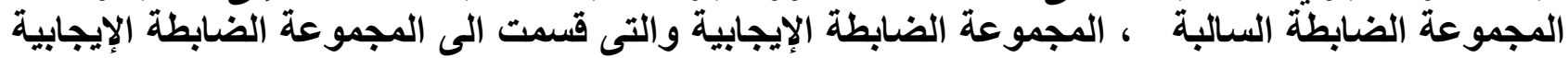

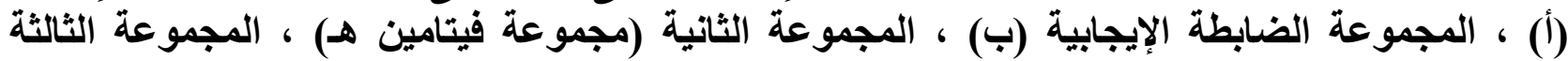



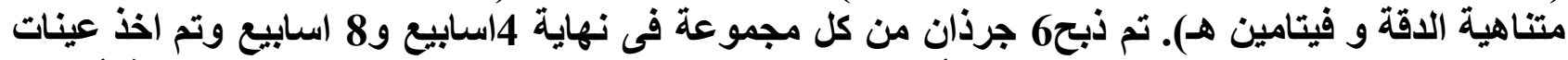

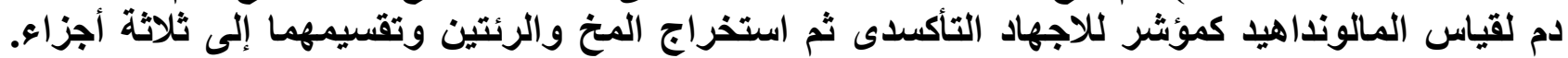



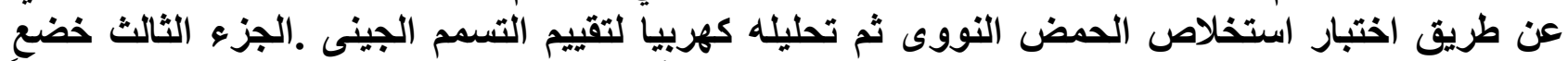
للفحص بالميكروسكوب الضوئى والفحص الكيميائي المناعي. أظهرت النتائج بعد تجميعها وتحليلها إحصائياً

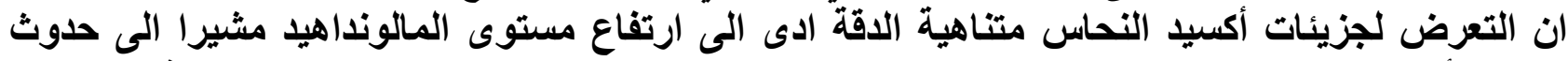

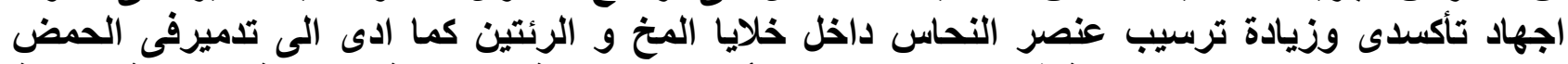

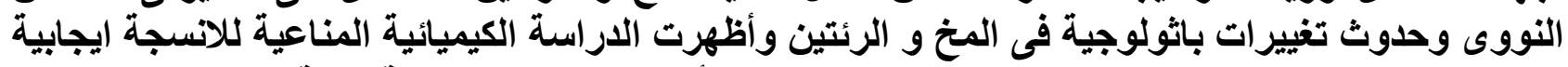

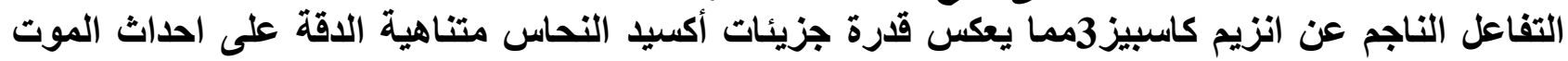

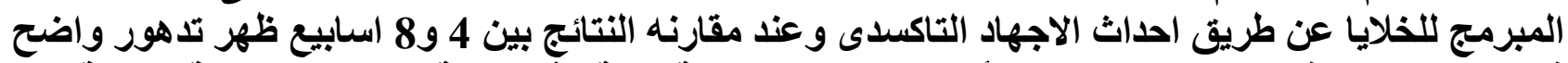

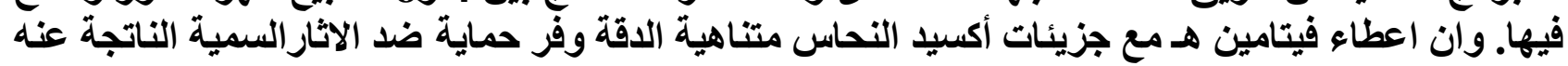

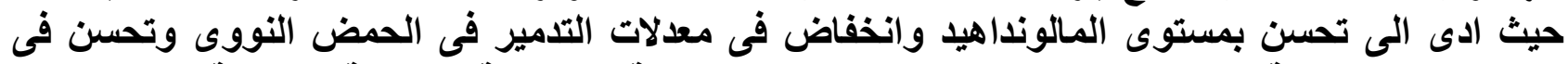

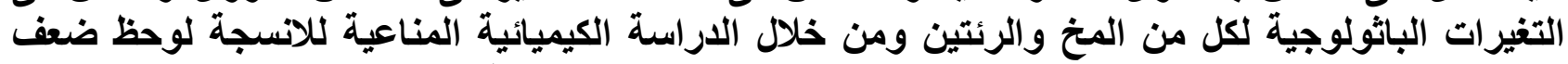

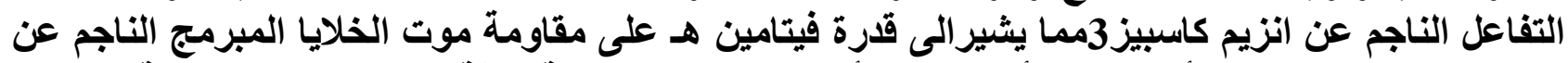

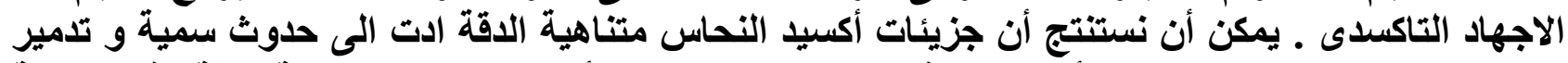

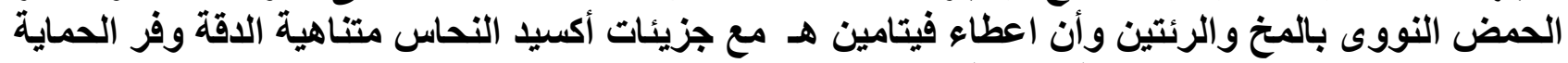

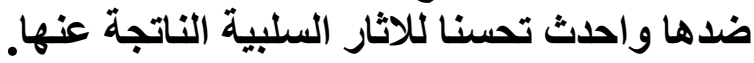

